\title{
Correction to: Resettled Refugee Teens' Perspectives: Identifying a Need to Centralize Youths'"Funds of Strategies" in Future Efforts to Enact Culturally Responsive Pedagogy
}

\section{Shannon M. Daniel ${ }^{1}$ - Maria Zybina ${ }^{1}$}

Published online: 12 November 2018

(c) Springer Nature B.V. 2018

\section{Correction to: The Urban Review https://doi.org/10.1007/s11256-018-0484-7}

The original version of this article unfortunately contained a mistake in the coauthor name. The co-author name should be Maria Zybina instead it was published incorrectly as Mariz Zybina.

The original article has been corrected.

The original article can be found online at https://doi.org/10.1007/s11256-018-0484-7.

Shannon M. Daniel

shannon.m.daniel@vanderbilt.edu

Maria Zybina

zybinamaria32@gmail.com

1 Department of Teaching and Learning, Vanderbilt University's Peabody College, PMB 230, 230 Appleton Place, Nashville, TN 37203, USA 